\title{
NDVI Based assessment of land cover changes using remote sensing and GIS-(A case study of Srinagar district, Kashmir)
}

\section{Evaluación basada en el NDVI de los cambios en la cubierta terrestre utilizando la teledetección y el GIS (estudio de caso del distrito de Srinagar, Kashmir)}

\author{
Perminder Singh ${ }^{1}$, Ovais Javeed ${ }^{2}$ \\ ${ }^{1}$ Centre for Climate Change and Mountain Agriculture Skuast-K, 190025 \\ ${ }^{2}$ Centre for Climate Change and Mountain Agriculture Skuast-K, 190025
}

\section{ABSTRACT}

Normalized Difference Vegetation Index (NDVI) is an index of greenness or photosynthetic activity in a plant. It is a technique of obtaining various features based upon their spectral signatures such as vegetation index, land cover classification, urban areas and remaining areas presented in the image. In the present study, the NDVI differencing method using Landsat 7 ETM+ images and Landsat OLI were implemented to assess the change in vegetation cover from 2001 to 2017 using the Natural Breaks (Jenks) method. NDVI values calculated from the satellite image of the year 2001 range from 0.62 to -0.41 and that of the year 2017 ranges from 0.53 to -0.10 based upon their spectral signature. The NDVI method is applied according to its characteristics like vegetation at different NDVI threshold values such as $-0.1,-0.09,0.14,0.06,0.28,0.35$, and 0.5 . Afterwards, a Difference NDVI map between 2001 and 2017 is generated to identify negatively or positively values of land cover changes. Results confirmed that the area without vegetation, such as water bodies, built-up areas and as well as barren lands, increased from $35 \%$ in 2001 to $39.67 \%$ in 2017 . The densely vegetated area decreased from $8.62 \%$ to $2.15 \%$ indicating the need to develop new policies in the city to protect vegetation areas during economic and urban development in the city of Srinagar.

Keywords: Normalized Difference Vegetation Index, land use/landcover, spectral signature

\section{Resumen}

El Índice de Vegetación de Diferencia Normalizada (NDVI) es un índice de actividad verde o fotosintética en una planta. Es una técnica para obtener varias características en función de sus firmas espectrales, como el índice de vegetación, la clasificación de la cobertura del suelo, las áreas urbanas y las áreas restantes que se presentan en la imagen. En el presente estudio, se implementó el método de diferenciación NDVI utilizando imágenes de mapeo temático Landsat y Landsat OLI para evaluar el cambio en la cubierta vegetal de 2001 a 2017 utilizando el método Natural Breaks (Jenks). Valores NDVI calculados a partir de la imagen de 
satélite de los rangos del año 2001 de 0.62 a -0.41 y el del año 2017 varía de 0.53 a -0.10 en función de su firma espectral. El método NDVI se aplica de acuerdo con sus características como la vegetación en diferentes valores umbral de NDVI, como -0.1, -0.09, 0.14, 0.06, 0.28, 0.35 y 0.5 Luego, se genera un mapa de NDVI de diferencia entre 2001 y 2017 para negativa o positivamente Identificar los valores de los cambios en la cobertura del suelo. Los resultados confirmaron que el área sin vegetación, como cuerpos de agua, así como áreas urbanizadas y tierras áridas, aumentó de 35\% en 2001 a 39.67\% en 2017. El área densamente vegetada disminuyó de $8.62 \%$ a $2.15 \%$ indicando la necesidad desarrollar nuevas políticas en la ciudad para proteger las áreas de vegetación durante el desarrollo económico y urbano en la ciudad de Srinagar.

Palabra claves: Índice de vegetación de diferencia normalizada, uso del suelo / cobertura del suelo, firma espectral

\section{INTRODUCTION}

The multi-spectral data collections from Multi-spectral Remote Sensing provide resourceful information and an improved perspective on Earth's environment, (Ahmadi $\mathrm{H}$ et al., 2012). A multi-spectral image shows several indicators for emphasizing vegetation-bearing areas. Satellite imagery refers to significant data which is commonly used in extracting change values of land cover (Nath B et al., 2014). The NDVI index is one of the most important indicators used by remote sensing to classify vegetation coverage for various periods and fields. The NDVI is defined as an indicator of measuring the balance among the energy received and emitted by earth objects (Tovar et al., 2012) Features rely on the individuality of reflection and indexes were developed to show the features of the image's interest (Xie y et al., 2010). It is an important index of vegetation widely used in research on global climate and environmental change (Gao et al., 1996). NDVI is a method of obtaining diverse features based on its spectral signatures such as vegetation index, classification of land cover, the structure of concrete, street construction, urban areas, rocky areas and other areas in the image (Sahebjalal and Dashtechian, 2013). NDVI was used significantly to detect changes in land cover due to human activities such as building and development as well as to analyze spatial and temporal changes in the area coverage of vegetation (Woodcock et al., 2002; Lunetta et al., 2006, Schmidt et al., 2000). In the Srinagar district, available vegetation may be a precious natural resource, and its distribution maps are vital for the management and development of resources. Today, the GIS includes sophisticated software that can be used in vegetation monitoring (Lambin et al., 2001) with Remote Sensing (RS) technologies. The key element of GIS is that attributes are related spatial and some system is utilized to process and analyze these relationships (Lillesand et al., 2009). In recent times the use of remote sensing knowledge has been important to facilitate and monitor the ever-changing vegetation pattern. The detection of change is the temporal effect in spectral reaction variation and involves situations in which the 
spectral properties of the vegetation or other cover types change over time at a given location (Agone et al., 2012; Bid et al., 2016).

NDVI

NDVI is a grade or photosynthesis index for plants. This satellite image alternative to vegetation productivity is universally used and easy to calculate (Kunkel et al., 2011; Scanlon et al.2002). NDVI is a simple statistical indicator for synthetically active radiation (PAR), mainly measuring the perspective of leaves and foreshadowing vegetation on the earth's surface over wide spaces (Demirel et al., 2010; Ricotta et al., 1990; Zhang et al., 2009). The NDVI is a simple statistical indicator. In this index, the photosynthesis, vegetation cover, biomass and Leaf Area Index (LAI) is shown as positive. The NDVI is calculated by removing the red reflectance values from the near-infrared and dividing them by the sum of the near-infrared and red band. (Tucker et al., 1979; Hu Y et al., 2008) .The function used is the following.

$$
N D V I=N I R-R E D / N I R+R E D
$$

(Whenever the spectral reflectance of the near-infrared band is represented by NIR, while the red band is represented by RED.) The extremely low NDVI value is equivalent to regions such as rock, sand, snow, clouds, etc. Moderate values, while temperate and tropical rainforests are indicative of high value. NDVI values nearest 0 are the bare soil and the water bodies with negative NDVI values are represented (Karaburun et al., 2010; Chouhan et al., 2011)

\section{MATERIAL AND METHODS}

Study Area: Srinagar the largest city summer capital of state Jammu and Kashmir. It lies on the banks of river Jhelum, a tributary of river Indus. Srinagar district lies between $34^{\circ} 0^{\prime} \mathrm{N}$ to $34^{\circ} 15^{\prime} \mathrm{N}$ latitude and $74^{\circ} 45^{\prime} \mathrm{E}$ to $74^{\circ} 0^{\prime} \mathrm{E}$ longitude at an average elevation of about 1552-4363 (AMSL). The topography of the district is diverse with both mountainous and plain areas. while the eastern and northeast part is the hilliest, the western and southern part of the district is plain. The district is alluvial filled basin similar to the valley, the karewas formation in the valley belong to Pleistocene and post Pleistocene age having horizontally stratified depositions of lacustrine origin beds of sand. The Srinagar district is spread across an area of 47846.82 hectares.

The climate of the Srinagar is of temperate type with the upper-reaches receiving high snowfall in winter and an average annual rainfall of about $820 \mathrm{~mm}$. The common plants in the study area are willow (salix alba), poplar (populous alba), false acacia (robinia pseudo acacia) etc..The hilly ranges are covered with forest species viz., deodar (cedrus deodara), chir (Pinus wallichiana), fir (abies pindrow) and other forest species. 
Methodology: In this Section, the NDVI technique is used to reveal quantitative assessment of vegetation cover change of a part of Srinagar district. For digital image processing, remote sensing and GIS-based software ( ArcGIS) were used for image processing, classification, analysis and NDVI map generation respectively to achieve the objectives of the study. ArcGIS is used to generate the false colour composite, by combining near-infrared (NIR), red and green of (Landsat 7 2001) and (Landsat 8 2017). Changes during the period (20012017) were analyzed using the NDVI differencing technique following (Singh et al., 1989).
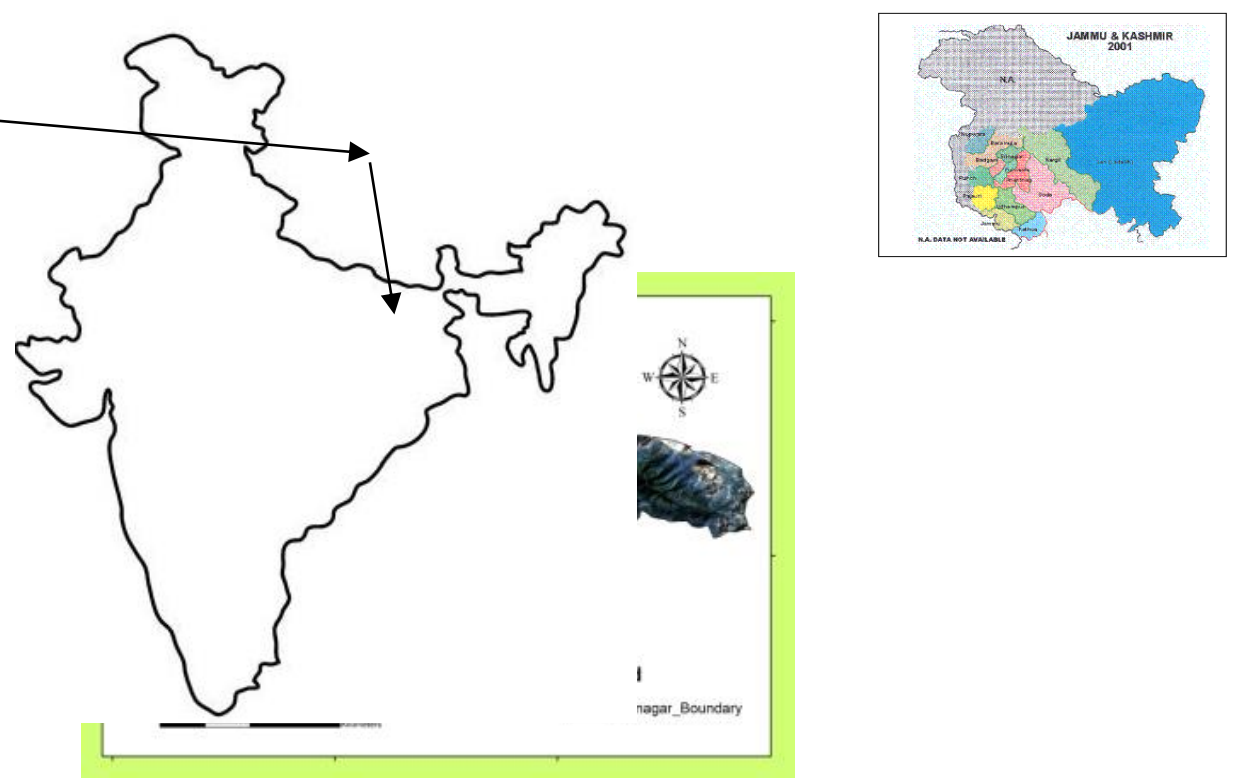

Fig 1 study area.

First, we calculated Reflectance value from the Satellite data Landsat8 OLI. Landsat 8 OLI spectral radiance data has also been converted to planetary TOA reflectance us ing

coefficients of reflectance rescaling provided in landsat8 OLI file. For converting DN values int o TOA reflection in the OLI image is used in the following equation:

$$
\rho \lambda^{\prime}=M \rho Q \mathrm{cal}+\mathrm{A} \rho
$$
eqn. 1

$\rho \lambda^{\prime}=$ TOA planetary reflectance, without correction for the solar angle. Note that $\rho \lambda^{\prime}$ does not contain a correction for the sun angle. $M \rho=$ Band-specific multiplicative rescaling factor from the metadata. A $\rho=$ Band-specific additive rescaling factor from the metadata Qcal = Quantized and calibrated standard product pixel values (DN).

Step 2:

Correcting the Reflectance value with the sun angle

Reflectance with a correction for the sun angle is then:

$$
\rho \lambda=\rho \lambda ' \cos \theta S Z=\rho \lambda ' / \sin \theta \text { SE }
$$


$\rho \lambda=$ TOA planetary reflectance, $\theta$ SE $=$ Local sun elevation angle. The scene centre sun elevation angle in degrees is provided in the metadata (Sun Elevation)., $\theta$ SZ = Local solar zenith angle; $\theta S Z=90^{\circ}-\theta$ SE.

Step 3

NDVI following the general normalized difference between (near-infrared- NIR) and band (visible red -RED) from the two Landsat pre-processed images (2001 and 2017 - eqn. 3):

$$
\text { NDVI }=\text { NIR-R/NIR+R } \quad \text {...................... eqn.3 }
$$

To evaluate the $\triangle$ NDVI image, the resulting images were subtracted with positive (NDVI increase) and negative (NDVI decrease) changes with a resolution of $30 \times 30 \mathrm{~m}$ of the pixel (eqn. 4):

$$
\Delta \text { NDVI=NDVI } 2017-\text { NDVI } 2001
$$

This false-colour composite was used to recognize vegetation. It was the classification of chlorophyll as a result of plants that are well reflected in the near-infrared rather than the visible band. Single NDVI maps were developed for 2001 and 2017. The NDVI was used to detect changes in vegetation area and quantify different year-wise quantitative data from NDVI using remote sensing, GIS software and tablets. The standardized vegetation difference index (NDVI) was used. The following flow chart mode also shows the method used for the present research.

Acquisition and selection of data: The image of the study area has been acquired during October with minimum cloud cover standard FCC imagery generated using a combination of spectral bands on a scale of 1:20,000. Landsat data is one of the most important and accurate data sets available in the United States Geological Survey (USGS), to understand the global land cover status. Two Landsat images were downloaded from www.glovis.usgs.gov on 0ct, 2001 and 0ct 2017 of the same path and row (149/36) for the change detection of vegetation cover of the study area. The image of 2001 is Landsat 7 ETM+ (Enhanced Thematic Mapper +) and that of the year 2017 is Landsat 8 OLI (Operational Land Imager). Main features of these two Landsat data sets are shown by the table1 below.

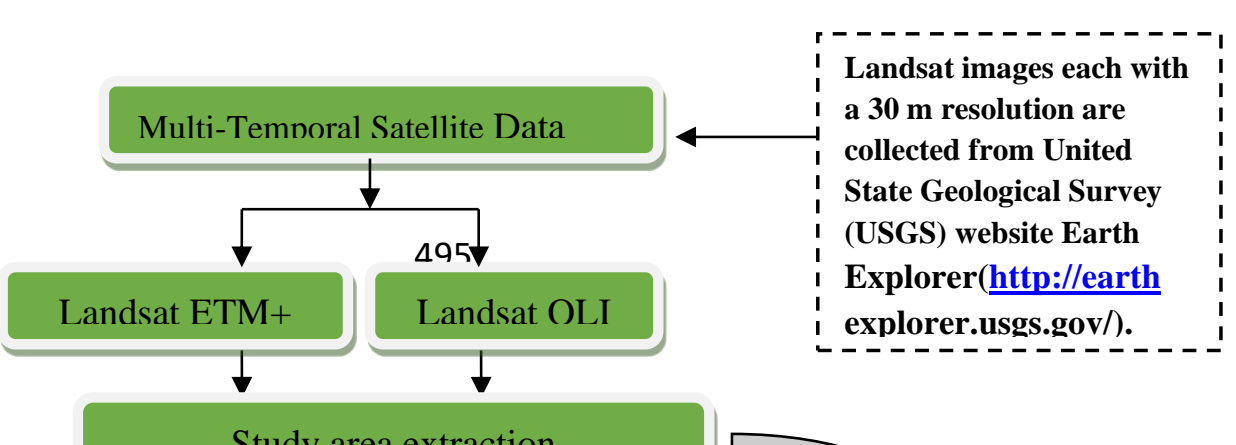


Sustainability, Agri, Food and Environmental Research, (ISSN: 0719-3726), 9(4), 2021: 491-504 http://dx.doi.org/10.7770/safer-VONO-art2174

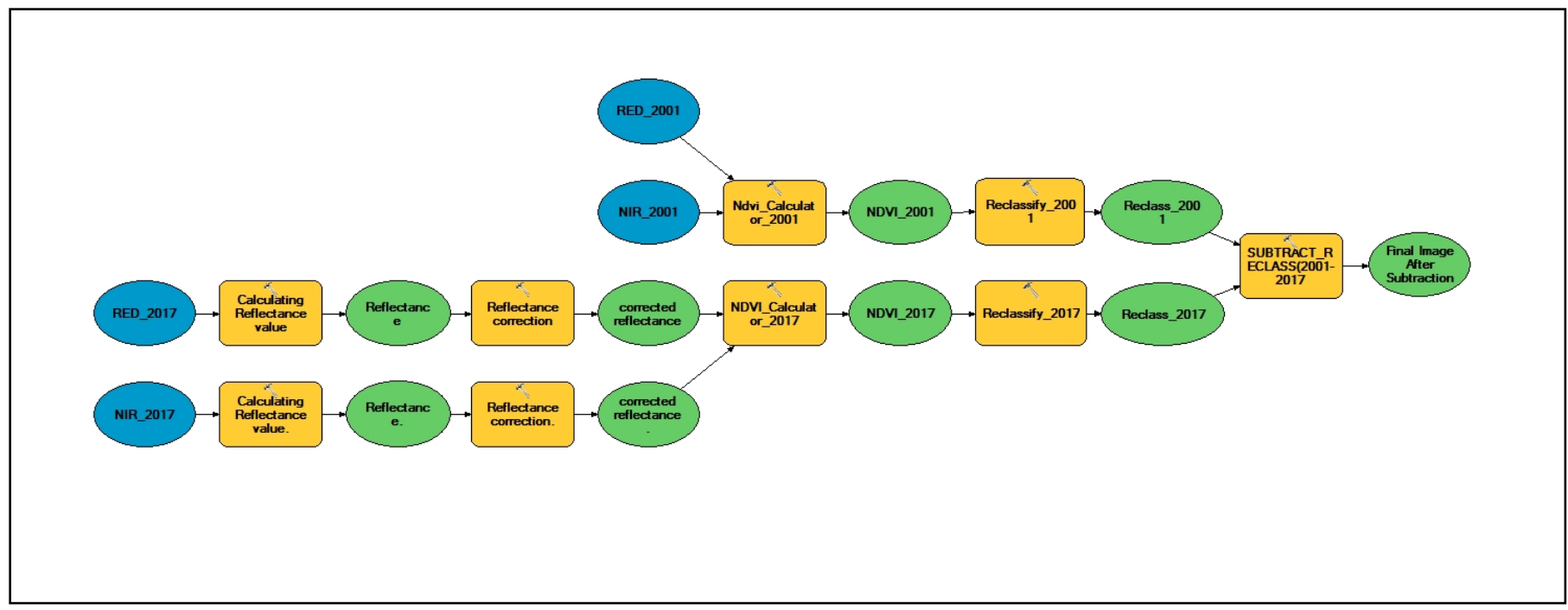

Fig.2 Schematic diagram of the model used in the study

Table 1 showing satellite data characteristics 
Sustainability, Agri, Food and Environmental Research, (ISSN: 0719-3726), 9(4), 2021: 491-504 http://dx.doi.org/10.7770/safer-VONO-art2174

\begin{tabular}{llcl}
\hline \multicolumn{1}{c}{ ETM+ } & \multicolumn{2}{c}{ OLI } & \\
\hline Acquisition date: October 2001 & Acquisition date: October 2017 \\
Band $(\mu \mathrm{m})$ & Resolution & Band $(\mu \mathrm{m})$ & Resolution \\
$0.433-0.453$ & $30 \mathrm{~m}$ & $0.435-0.451$ & $30 \mathrm{~m}$ \\
$0.450-0.515$ & $30 \mathrm{~m}$ & $0.452-0.512$ & $30 \mathrm{~m}$ \\
$0.525-0.600$ & $30 \mathrm{~m}$ & $0.533-0.590$ & $30 \mathrm{~m}$ \\
$0.630-0.680$ & $30 \mathrm{~m}$ & $0.636-0.673$ & $30 \mathrm{~m}$ \\
$0.845-0.885$ & $30 \mathrm{~m}$ & $0.851-0.879$ & $30 \mathrm{~m}$ \\
$1.560-1.660$ & $30 \mathrm{~m}$ & $1.566-1.651$ & $30 \mathrm{~m}$ \\
$2.100-2.300$ & $30 \mathrm{~m}$ & $2.107-2.294$ & $60 \mathrm{~m}$ \\
$0.500-0.680$ & $15 \mathrm{~m}$ & $0.503-0.676$ & $15 \mathrm{~m}$ \\
& & $1.363-1.384$ & $30 \mathrm{~m}$ \\
& & $10.60-11.19$ & $100 *(30) \mathrm{m}$ \\
\hline
\end{tabular}

Table 2 showing the band combinations used for the study to carry out NDVI

Band combination

\begin{tabular}{|c|c|c|c|c|c|c|}
\hline \multirow[t]{2}{*}{ Satellite data } & \multicolumn{3}{|c|}{ Landsat7 } & \multicolumn{3}{|c|}{ Landsat8 } \\
\hline & Blue & Green & RED & Blue & Green & RED \\
\hline True color & BAND 2 & BAND 3 & BAND 4 & BAND 1 & BAND 2 & BAND 3 \\
\hline RGB & BAND 4 & BAND 3 & BAND 2 & BAND 5 & BAND 4 & BAND 3 \\
\hline NDVI & NIR(band 3) & \multicolumn{2}{|c|}{ RED(band 4) } & NIR(band 5) & \multicolumn{2}{|c|}{ RED(band 4) } \\
\hline NDVI Data & \multicolumn{3}{|c|}{ (BAND 4-BAND 3)/(BAND4+BAND 3) } & \multicolumn{3}{|c|}{$($ BAND 5-BAND 4)/(BAND5+BAND 4) } \\
\hline NDVI Diff. & \multicolumn{6}{|c|}{ (NDVI)t-(NDVI)T } \\
\hline
\end{tabular}

RESULT AND DISCUSSION

The NDVI has been used widely to examine the relation between Spectral variability and the changes in vegetation growth rate. It is also useful to determine the production of green 
vegetation as well as to detect vegetation changes. The results, included in Table 2 , represent the band combination, which has been extracted from the satellite image of Srinagar district.

Image Differencing Analysis: After the analysis of satellite image Fig.4 (a), it has been found that the multispectral images are giving the best result for all the features at NDVI value. In this work, the NDVI value is varied from (0.4 to 0.6$)$ whereas second image Fig.4 (b), giving good result for all the features at NDVI value varied from (0.1 to 0.5$)$. As it can be seen the vegetation cover area has maximum NDVI values then comes the habitation, and finally, water body shows the least. From (Fig.3). Table-4 shows the variation of NDVI values for different classes at different threshold value Non-vegetation class increased from 16764.12 (ha) in 2001 to 18997.92 (ha) in 2017 showing a growth of $13.32 \%$ because of the increased rates of builtup areas. Most changes in the vegetation cover occurred at the centre of the city, where the main Srinagar town is located, as shown in (Fig. 3). The Sparse Vegetation class increased from 14136.12 (ha) in 2001 to 15474.96 (ha) in 2017 thus showing an increasing trend of $9.47 \%$ indicating the deforestation In those areas. Similarly, the Moderate vegetation class decreased from 13031.19 (ha) in 2001 to 12381.21 (ha) in 2017 which accounts for $4.98 \%$ decrease from the year 2001. while the Dense vegetation class decreased from 3955.5 (ha) in 2001 to 1032.84 (ha) in 2017 showing a negative change of $-73.8 \%$. The negative change indicates that the dense vegetation class has decreased to a large extent due to large scale Urban and economic development of the Srinagar district. For a vegetation index detection to be present on a satellite image, the NDVI process must be extracted from every unit. After the different band are separated, NDVI method is applied according to its characteristics like vegetation at different NDVI threshold values such as $-0.1,-0.09,0.14,0.06,0.28,0.35$, and 0.5 . NDVI maps are reclassified by a value of NDVI scale -1 to +1 , which corresponds to spectral reflection-based vegetation values. (Bharathkumar et al., 2015; Ramachandra et al., 2015). The negative value of an NDVI index refers to lack of vegetation and other types of land use such as built-up areas. Furthermore, a zero value indicates bodies of water, whereas positive values refer to different types of vegetation rates (Sun, J. et al., 2011; Morawitz et al., 2006). 


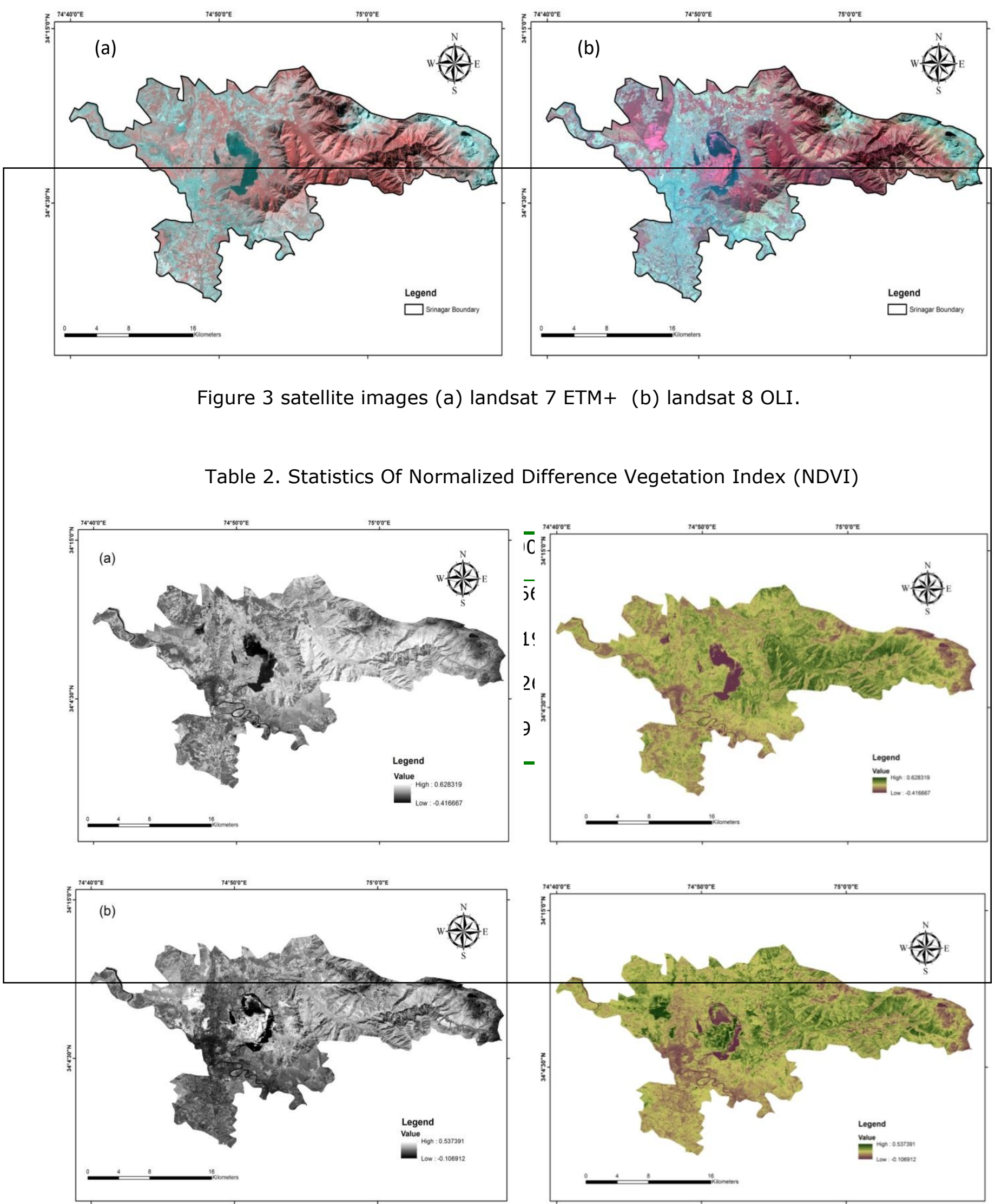


Sustainability, Agri, Food and Environmental Research, (ISSN: 0719-3726), 9(4), 2021: 491-504 http://dx.doi.org/10.7770/safer-VONO-art2174

Figure 4 (A)Showing Ndvi Map Of Landsat $2001 \mathrm{Etm}+$ and Fig 2(b) showing Ndvi map of landsat 8 OLI.

Table 4 Changes in the NDVI densities between 2001 and 2017

\begin{tabular}{|c|c|c|c|c|c|c|c|c|c|}
\hline \multirow[t]{2}{*}{ NDVI Density classes } & \multicolumn{3}{|c|}{2001 NDVI class Area } & \multicolumn{3}{|c|}{2017 NDVI class Area } & \multicolumn{2}{|c|}{$\begin{array}{l}\text { Change between } \\
\text { 2001-17 }\end{array}$} & \multirow{2}{*}{$\begin{array}{c}\text { Average Rate } \\
\text { Change } \\
\mathrm{Ha} / \text { Year }\end{array}$} \\
\hline & Cells & ha & $\%$ & Cells & ha & $\%$ & ha & $\%$ & \\
\hline NON-vegetation & 186268 & 16764.12 & 35 & 211088 & 18997.92 & 39.67 & 2233.8 & 13.32 & 139.6 \\
\hline Sparse-Vegetation & 157068 & 14136.12 & 29.51 & 171944 & 15474.96 & 32.31 & 1338.84 & 9.47 & 83.6 \\
\hline Moderate-Vegetation & 144791 & 13031.19 & 27.21 & 137569 & 21381.21 & 25.85 & -649.98 & -4.98 & 40.7 \\
\hline Dense-Vegetation & 43950 & 3955.5 & 8.26 & 11476 & 1032.84 & 2.15 & -2922.66 & -73.8 & 182.6 \\
\hline Total & 532077 & 47886.92 & 100 & 532077 & 47886.92 & 100 & - & - & \\
\hline
\end{tabular}
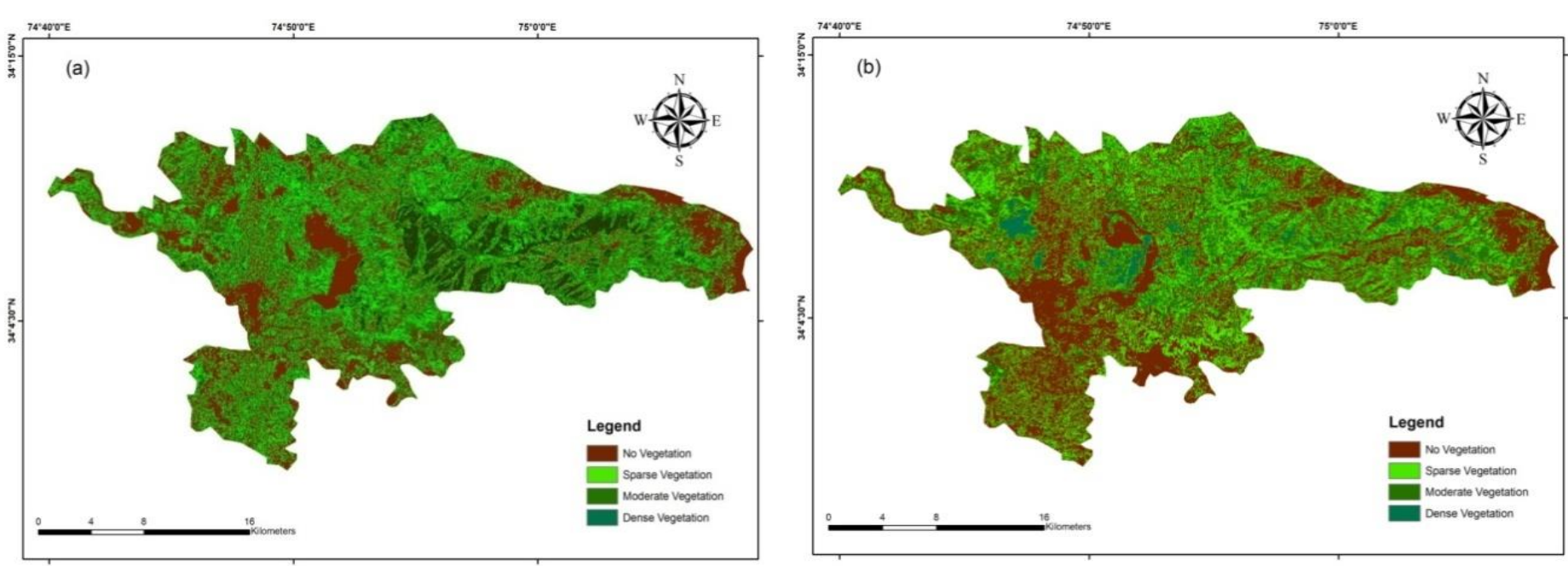

Figure 5 showing reclassified map of ndvi (a) landsat 2001 (b) landsat 8

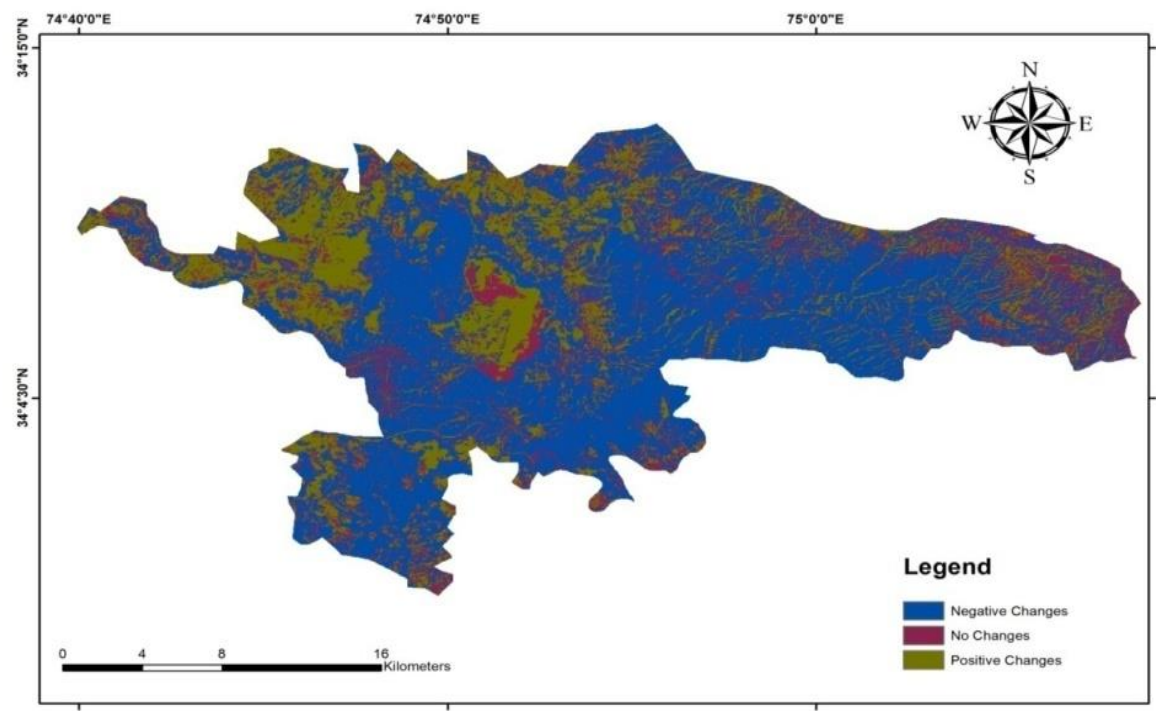


Figure 6 showing NDVI Difference map

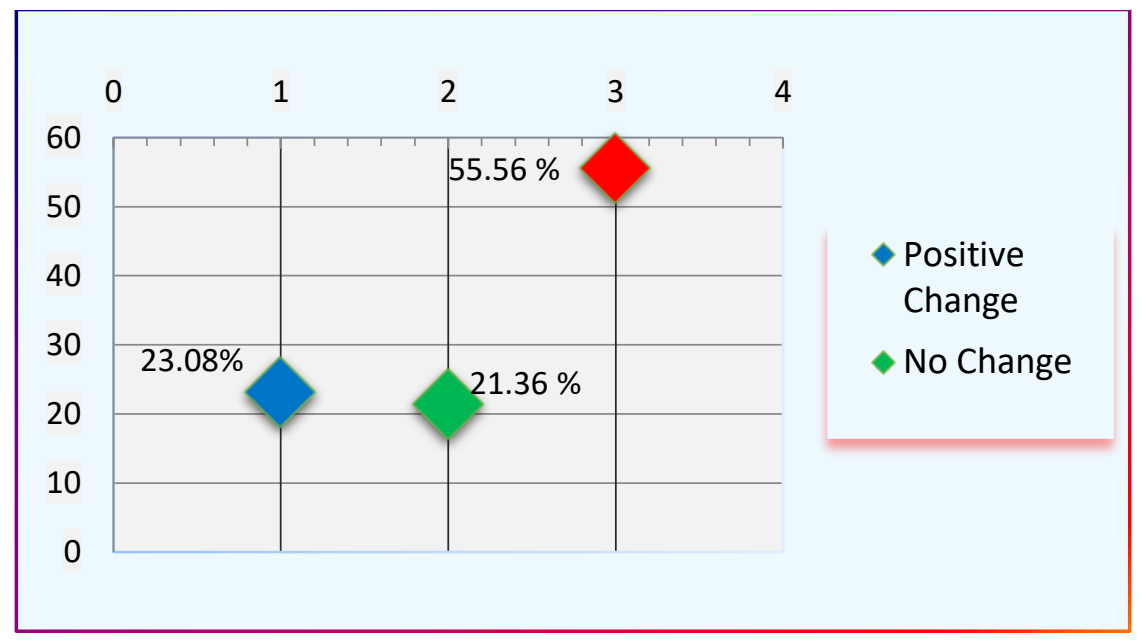

Fig. 7. NDVI difference values between period of 2001 to 2017 (\%).

An image classification is said to be incomplete unless its accuracy has been assessed. To set up the accuracy of classification, a sample of testing pixels is select on the category field images and their class compared with the reference knowledge (ground truth). The selection of sampling scheme and therefore the determination of an appropriate sample size for testing data play a vital role within the assessment of classification accuracy (Arora et al, 2002). Overall accuracy is a normal criterion that is employed to assess the accuracy of the classifications. The Overall accuracy was outlined because the total range of correctly classified pixels divided by the overall range of reference pixels (total number of sample points) (Rogan et al. 2002) To assess the accuracy of the NDVI result it's compared with the high resolution Google earth images and points of field investigation. 100 reference points were taken at random for every category. After the completion of each 2001 and 2017 NDVI maps Gps points were superimposed on the images them and known total four hundred points (100 points for every NDVI class) and note their coordinate values wherever the vegetation is removed in 2017 map at the Srinagar and its surrounding area. Then identify those coordinates in high resolution Google earth image of 2017 and also observe a similar points within the time of field visit by the help of GPS (Geographical Positioning System). Accuracy level is calculated on the basis of reference data viz. Google image and field verification which is shown within the table 5. The level of accuracy of the NDVI results is Nighty one.

Table 5 showing accuracy table 


\begin{tabular}{ccccc}
\hline & $\begin{array}{c}\text { Number of } \\
\text { samples taken }\end{array}$ & $\begin{array}{c}\text { No. of samples } \\
\text { matched with } \\
\text { Google earth,2017 }\end{array}$ & $\begin{array}{c}\text { No.of sample } \\
\text { match in field }\end{array}$ & $\begin{array}{c}\text { Average } \\
\text { accuracy level in } \\
\%\end{array}$ \\
\hline No vegetation & 100 & 85 & 90 & 87.5 \\
Sparse & 100 & 80 & 91 & 85.5 \\
Moderate & 100 & 85 & 90 & 87.5 \\
Dense & 100 & 100 & 100 & 100 \\
& Over all accuracy level in\% & & 90.120 \\
\hline
\end{tabular}

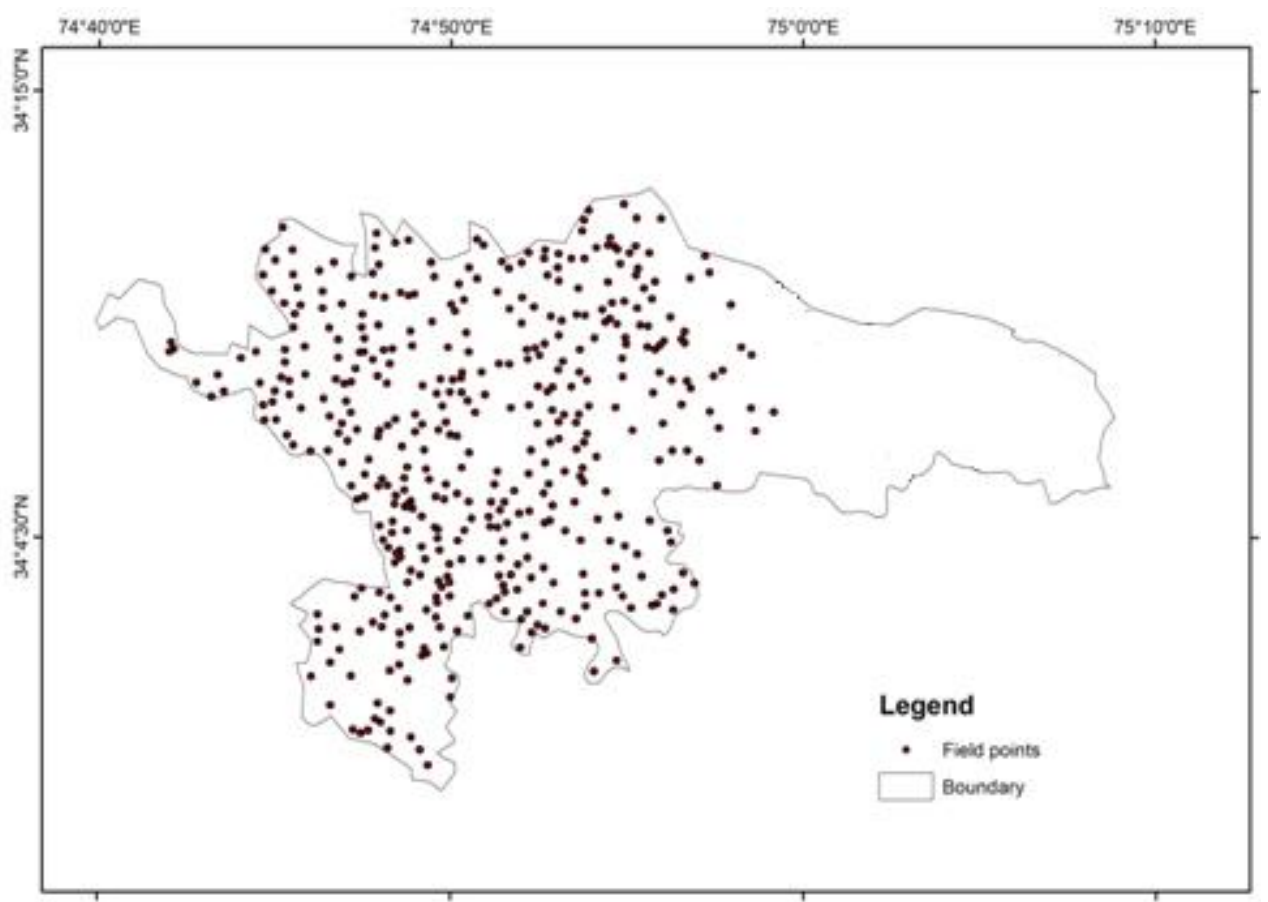

Figure 5 showing Ground Truth Points

Multi-temporal satellite remote sensing is a viable approach for identifying and monitoring vegetation changes over a period. This study detected the extent of Vegetation cover changes in the Srinagar city with the application of remote sensing and GIS technique by using satellite imageries. Results of the study showed that the dense vegetation areas in the study region were decreasing due to several factors, such as urban and economic growth. Dense vegetation is found to be $8.26 \%$, sparse vegetation is found to be $29.51 \%$, moderate vegetation is found to be $27.21 \%$. and the non-vegetated area is found to be $35 \%$ in the year 2001. While as the percentage of Dense vegetation is found to be $6.57 \%$, sparse vegetation is found to be $23.49 \%$, moderate vegetation is found to be $37.79 \%$ and no vegetation area is found to be $39.67 \%$ in the year 2017 . The negative changes in vegetation cover in Srinagar district that occurred between 2001 and 2017 at 55.56\% are due to land use activities based on the of urban and economic development Results of the NDVI index can be used as indicators for future trends on land cover changes and for identifying effective factors on vegetation cover for the better understanding of planners and decision-makers on the issue.

\section{References}

Agone,V., \& Bhamare, S. M. (2012). Change detection of vegetation cover using remote sensing and GIS. Journal of research and development, 2(4). 
Ahmadi,H., \& Nusrath, A. (2010). Vegetation change detection of Neka River in Iran by using Remote sensing and GIS. Journal of geography and geology, 2(1), 58

Arora, M. K., \& Agarwal, K., (2002): A program for sampling design for image classification accuracy assessment, Photogrammetry Journal of Finland, 18 (I), pp.33-43.

Bharathkumar, L,\& Mohammed-Aslam, M. A. (2015). Crop pattern mapping of tumkur taluk using NDVI technique: a remote sensing and GIS approach. Aquatic Procedia, 4, 13971404.

Bid, S. (2016). Change detection of vegetation cover by NDVI technique on catchment area of the Panchet hill dam, India. Int. J. Regul. Gov, 2(3), 11-20.

Chouhan, R.,\& Rao, N. (2011). Vegetation detection in multispectral remote sensing images: Protective role-analysis of vegetation in 2004 indian ocean tsunami. PDPM Indian Institute of Information Technology.

Demirel, H., Ozcinar, C.,\& Anbarjafari, G. (2009).Satellite image contrast enhancement using discrete wavelet transform and singular value decomposition.IEEE Geoscience and remote sensing letters, 7(2), 333-337.

Gao, B. C. (1996). NDWI-A normalized difference water index for remote sensing of vegetation liquid water from space. Remote sensing of environment, 58(3), 257-266.

Hu, Y., Ban, Y., Zhang, Q., Zhang, X., Liu, J., \& Zhuang, D. (2008, June). Spatial-temporal pattern of GIMMS NDVI and its dynamics in Mongolian Plateau. In 2008 International Workshop on Earth Observation and Remote Sensing Applications (pp. 1-6). IEEE.

Karaburun, A. (2010). Estimation of C factor for soil erosion modeling using NDVI in Buyukcekmece watershed. Ozean journal of applied sciences, 3(1), 77-85.

Kunkel, M. L., Flores, A. N., Smith, T. J., McNamara, J. P., \& Benner, S. G. (2011). A simplified approach for estimating soil carbon and nitrogen stocks in semi-arid complex terrain. Geo-derma, 165(1), 1-11.

Lambin, E. F., Turner, B. L., Geist, H. J., Agbola, S. B., Angelsen, A., Bruce, J. W., ... \& George, P. (2001). The causes of land-use and land-cover change: moving beyond the myths. Global environmental change, 11(4), 261-269.

Lillesand, T., Kiefer, R. W., \& Chipman, J. (2015). Remote sensing and image interpretation. John Wiley \& Sons.

Lunetta, R. S., Knight, J. F., Ediriwickrema, J., Lyon, J. G., \& Worthy, L. D. (2006). Land-cover change detection using multi-temporal MODIS NDVI data. Remote sensing of environment, 105(2), 142-154.

Morawitz, D. F., Blewett, T. M., Cohen, A., \& Alberti, M. (2006). Using NDVI to assess vegetative land cover change in central Puget Sound. Environmental monitoring and assessment, 114(1-3), 85-106. 
Nath, B. (2014). Quantitative assessment of forest cover change of a part of Bandarban Hill tracts using NDVI techniques. Journal of Geosciences and Geomatics, 2(1), 21-27.

Ramachandra, T. V., \& Kumar, U. (2004, September). Geographic Resources Decision Support System for land use, land cover dynamics analysis. In Proceedings of the FOSS/GRASS users conference (pp. 12-14).

Rogan, J., Franklin, J., \& Roberts, D. A. (2002). A comparison of methods for monitoring multitemporal vegetation change using Thematic Mapper imagery. Remote sensing of environment, 80(1), 143-156.

Sahebjalal, E., \& Dashtekian, K. (2013). Analysis of land use-land covers changes using normalized difference vegetation index (NDVI) differencing and classification methods. African Journal of Agricultural Research, 8(37), 4614-4622.

Scanlon, T. M., Albertson, J. D., Caylor, K. K., \& Williams, C. A. (2002). Determining land surface fractional cover from NDVI and rainfall time series for a savanna ecosystem. Remote Sensing of Environment, 82(2-3), 376-388.

Schmidt, H., \& Karnieli, A. (2000). Remote sensing of the seasonal variability of vegetation in a semi-arid environment. Journal of arid environments, 45(1), 43-59.

Singh, A. (1989). Review article digital change detection techniques using remotely-sensed data. International journal of remote sensing, 10(6), 989-1003.

Sun, J., Wang, X., Chen, A., Ma, Y., Cui, M., \& Piao, S. (2011). NDVI indicated characteristics of vegetation cover change in China's metropolises over the last three decades. Environmental monitoring and assessment, 179(1-4), 1-14.

Tovar, C. L. (2012). Meneses.,"NDVI as indicator of Degradation,". Unasy/va, 62, 238.

Tucker,C.J.(1979 Red and photographic infrared linear combinations for monitoring vegetation, J Remote Sens Environ, 10 (1), pp. 23-32.

Woodcock, C. E., Macomber, S. A., \& Kumar, L. (2002). Vegetation mapping and monitoring. Environmental modelling with GIS and remote sensing, 97-120.

Xie, Y., Zhao, X., Li, L., \& Wang, H. (2010, June). Calculating NDVI for Landsat7-ETM data after atmospheric correction using 6S model: A case study in Zhangye city, China. In 2010 18th International Conference on Geoinformatics (pp. 1-4). IEEE.

Zhang, X., Hu, Y., Zhuang, D., Qi, Y., \& Ma, X. (2009). NDVI spatial pattern and its differentiation on the Mongolian Plateau. Journal of geographical sciences, 19(4), 403415. 